\title{
RESPONS TANAMAN KACANG HIJAU (Vigna radiata L.) TERHADAP PEMBERIAN PUPUK ORGANIK KOMPOS AMPAS TEBU
}

\author{
Elly Indraswari, Yulia Alia dan Nerty Soverda ${ }^{1}$
}

Email: nsoverda@yahoo.com

\begin{abstract}
ABSTRAK
Tanaman kacang hijau merupakan jenis tanaman yang termasuk dalam suku polongpolongan (Fabaceae) yang menghasilkan biji yang mengandung banyak karbohidrat dan protein. Di Provinsi Jambi sebagian besar budidaya tanaman kacang hijau dilakukan pada lahan ultisol. Tanah ultisol merupakan jenis tanah miskin kandungan hara makro terutama $\mathrm{P}, \mathrm{K}, \mathrm{Ca}, \mathrm{Mg}$ dengan kandungan bahan organik yang rendah. Alternatif yang dapat dilakukan adalah selain menambahkan pupuk anorganik juga dapat dilakukan penambahan bahan organik seperti pupuk kompos ampas tebu. Penelitian ini menggunakan Rancangan Acak Kelompok (RAK) dengan satu faktor yaitu dosis pupuk kompos ampas tebu yang terdiri atas 4 taraf perlakuan yaitu tanpa pupuk kompos ampas tebu (p0), 10 ton ha ${ }^{-1}$ pupuk kompos ampas tebu (p1), 20 ton ha ${ }^{-1}$ pupuk kompos ampas tebu (p2) dan 30 ton $\mathrm{ha}^{-1}$ pupuk kompos ampas tebu (p3). Setiap perlakuan diulang sebanyak 6 kali dengan demikian terdapat 24 petakan percobaan. Setiap petakan percobaan terdiri dari 4 tanaman sampel. Untuk melihat pengaruh perlakuan terhadap variabel yang diamati lakukan Uji Anova dan Uji Lanjut Duncan. Hasil penelitian menunjukkan bahwa pemberian kompos ampas tebu dengan dosis 10 ton ha ${ }^{-1}$ adalah merupakan dosis terbaik untuk parameter bobot 100 , hasil (ton $\mathrm{ha}^{-1}$ ) dan nilai indeks panen.
\end{abstract}

Kata kunci: Kacang hijau, kompos ampas tebu

\begin{abstract}
Mung bean plants belong to Family Fabaceae whichits seeds contain lots of carbohydrates and protein. In Jambi Province, most of mung bean cultivation is applied on ultisol land. Ultisol soil type is a poor soil containing macro nutrients, especially Phospor, Kalium, Calcium and Magnesium with low organic matter content. To increase the productivity of ultisol soil, an alternative that can be done is to add inorganic fertilizer. Besides, the bagasse compostcan be applied. This study used a Randomized Block Design (RBD) with one factor: dose of bagasse compost fertilizer consisting of 4 levels of treatment: without bagasse compost fertilizer (p0), 10 tons $\mathrm{ha}^{-1}$ bagasse bagasse compost (p1), 20 tons $\mathrm{ha}^{-1}$ bagasse compost fertilizer (p2) and 30 tons $^{-1} \mathrm{a}^{-1}$ bagasse compost fertilizer (p3). Each treatment was repeated 6 times so there were 24 trial maps. Each plot of the experiment consists of 4 sample plants. Data analysis subjected to ANOVA Test and means were analyzed with DMRT Test.The results revealed that the application of bagasse compost at a dose of 10 tons $\mathrm{ha}^{-1}$ was the best dose for the parameters of weight 100 , yield $\left(\right.$ ton $\mathrm{ha}^{-1}$ ) and the value of the harvest index.
\end{abstract}

Keywords: Mung bean, bagasse compost, ultisol, yield

\footnotetext{
${ }^{1}$ Jurusan Agroekoteknologi Fakultas Pertanian Universitas Jambi
} 


\section{Pendahuluan}

Tanaman kacang hijau merupakan tumbuhan yang termasuk suku polongpolongan (Fabaceae) ini memiliki banyak manfaat dalam kehidupan seharihari sebagai sumber bahan pangan berprotein nabati tinggi. Kacang hijau di Indonesia menempati urutan ketiga terpenting sebagai tanaman pangan legum, setelah kedelai dan kacang tanah (Bimasri, 2014). Kandungan proteinnya yang tinggi membuat biji kacang hijau dapat digunakan sebagai sumber alternatif untuk memenuhi kebutuhan protein selain protein hewani. Menurut Lasmaria et al., (2016) kandungan zat dalam kacang hijau bermanfaat untuk mengatasi berbagai macam penyakit seperti beri-beri, anemia, wasir, gangguan hati dan lain-lain.

Produksi dan produktivitas kacang hijau di Indonesia masih tergolong rendah. Menurut data Badan Pusat Statistik bahwa produksi kacang hijau di Indonesia tahun 2015 adalah sebesar 271.420 ton dengan produktivitas 1,2 ton ha $^{-1}$ sedangkan produksi kacang hijau di Provinsi Jambi pada tahun yang sama adalah 129 ton dengan produktivitas 1,1 ton $\mathrm{ha}^{-1}$. Rata-rata daya hasil kacang hijau dapat mencapai 1,5 ton ha ${ }^{-1}$ (Balai Penelitian Kacang-kacangan dan Umbiumbian, 2005). Soeprapto (1993) juga menyatakan bahwa produksi kacang hijau dapat meningkat mencapai 2,5-2,8 ton $\mathrm{ha}^{-1}$ apabila lingkungan sekitar dalam keadaan baik. Hal ini menunjukkan bahwa masih terbuka peluang yang cukup besar untuk meningkatkan produktivitas kacang hijau.

Tanah yang memiliki tingkat kesuburannya rendah mencirikan bahwa tanah tersebut miskin akan unsur hara contohnya pada tanah ultisol. Tanah ultisol memiliki tingkat kemasaman tinggi, $\mathrm{pH}$ rata-rata $<4,50$, kejenuhan $\mathrm{Al}$ tinggi, miskin kandungan hara makro terutamaa $\mathrm{P}, \mathrm{K}, \mathrm{Ca}, \mathrm{Mg}$ dan kandungan bahan organik yang rendah (Prasetyo dan Suriadikarta, 2006). Penambahan pupuk dapat membantu untuk mencukupi kebutuhan akan unsur hara.

Pupuk terbagi atas dua jenis yaitu pupuk organik dan anorganik. Pupuk organik adalah pupuk yang berasal dari bahan-bahan alami berupa jasad renik yang mudah terurai di dalam tanah dan tidak menimbulkan kerusakan pada tanah. Pupuk anorganik adalah jenis pupuk kimia yang menghasilkan residu berbahaya dan menyebabkan kerusakan tanah. Menurut Musnamar (2003) penggunaan pupuk organik yang dipadukan dengan penggunaan pupuk kimia dapat meningkatkan produktivitas tanaman dan pengurangan penggunaan pupuk kimia, baik dilahan sawah maupun dilahan kering.

Banyak bahan alami yang dapat digunakan sebagai bahan dasar pupuk organik, salah satunya yaitu ampas tebu. Limbah ini banyak mengandung serat dan gabus. Marum et al., (2012) melaporkan hasil samping industri gula di Indonesia berupa ampas (bagasse) sebesar 47,77 \% dan masih memiliki kandungan air 48-52 \%. Ampas tebu dapat diaplikasikan ke tanaman apabila telah dilakukan proses dekomposisi dengan bantuan bioaktivator yang bisa digunakan barasal dari Effective Mikroorganism 4 (EM4). Yuliani dan Nugraheni (2010) mengemukakan pembuatan pupuk organik ampas tebu yang dikombinasikan dengan kotoran sapi dan arang sekam menggunakan perbandingan 3:1:1 terkandung kadar air $64,23 \%$, C 26,5\%, N 1,4\%, rasio C/N $18.9, \mathrm{P}_{2} \mathrm{O}_{5} 1,7 \%, \mathrm{~K}_{2} \mathrm{O} 1,8 \%$.

Nilai hara yang terkandung dari hasil penelitian Yuliani dan Nugraheni (2010) sudah memenuhi standar kualitas 
kompos, akan tetapi untuk hasil penelitian Guntoro et al., (2003) pada nilai $\mathrm{K}$ yang dihasilkan masih belum memenuhi nilai standar kualitas kompos. Nilai Standar kualitas kompos yang di kehendaki yaitu $\mathrm{N}$ minimal $0,4 \%$, C minimal 9,8\% dan maksimal $32 \%, \mathrm{P}$ minimal $0,1 \%, \mathrm{~K}$ minimal 0,2 dan rasio $\mathrm{C} / \mathrm{N}$ minimal $10 \%$ dan maksimal $20 \%$ (Standar Nasional Indonesia, 2010). Dengan demikian pupuk ampas tebu dengan kombinasi kotoran sapi dapat digunakan dan mampu menambah unsur hara yang dibutuhkan oleh tanaman.

\section{Bahan dan Metode}

Penelitian ini dilaksanakan di Kebun Percobaan Fakultas Pertanian Universitas Jambi, Mendalo Indah Kecamatan Jambi Luar Kota, Kabupaten Muaro Jambi. Pada penelitian ini dilakukan dengan menggunakan Rancangan Acak Kelompok (RAK) dengan satu faktor yaitu dosis pupuk organik kompos ampas tebu yang terdiri atas 4 taraf perlakuan. Setiap perlakuan diulang sebanyak 6 kali dengan demikian terdapat 24 petakan percobaan. Ukuran petakan masing-masing adalah $200 \mathrm{~cm}$ x $120 \mathrm{~cm}$, jumlah tanaman dalam satu petakan sebanyak 40 tanaman dengan jarak tanam $30 \mathrm{~cm}$ x $20 \mathrm{~cm}$. Pada setiap petak percobaan diambil 4 tanaman sebagai sampel. Jarak antar ulangan $100 \mathrm{~cm}$ dan jarak antar perlakuan dalam ulangan $50 \mathrm{~cm}$. Adapun perlakuan yang digunakan dalam penelitian ini adalah: $\mathrm{p}_{0}=$ Tanpa pemberian pupuk organik kompos ampas tebu, $\mathrm{p}_{1}=$ Pemberian pupuk organik kompos ampas tebu 10-ton ha ${ }^{-1}, \mathrm{p}_{2}=$ Pemberian pupuk organik kompos ampas tebu 20-ton $\mathrm{ha}^{-1}$, dan $\mathrm{p}_{3}=$ Pemberian pupuk organik kompos ampas tebu 30ton $\mathrm{ha}^{-1}$.

Variabel yang diamati meliputi tinggi tanaman, jumlah cabang primer per tanaman, karbohidrat daun, jumlah polong per tanaman, jumlah polong berisi per tanaman, bobot 100 biji, dan hasil per hektar. Data pengamatan yang diperoleh dianalisa secara statik menggunakan analisa sidik ragam pada taraf 5\%. Untuk mengetahui pengaruh akibat perlakuan yang dicobakan, maka dilakukan uji lanjut DMRT taraf $\alpha=5 \%$.

\section{Hasil dan Pembahasan}

Perlakuan dosis ampas tebu tidak menyebabkan perubahan pada peubah pertumbuhan tanaman kacang hijau. Perubahan yang terjadi pada peubah pertumbuhan yang diamati adalah tinggi tanaman dan jumlah cabang primer kacang hijau. Perubahan-perubahan tersebut dapat dilihat pada Tabel 1 berikut.

\begin{tabular}{|c|c|c|c|c|}
\hline \multicolumn{5}{|c|}{ Tinggi tanaman } \\
\hline $\begin{array}{l}\mathrm{N} \\
\mathrm{o} .\end{array}$ & $\begin{array}{l}\text { Perla } \\
\text { kuan }\end{array}$ & $\begin{array}{c}\text { Tinggi } \\
\text { Tanaman }\end{array}$ & NR & $\begin{array}{l}\text { Per } \\
\text { uba } \\
\text { han } \\
(\%)\end{array}$ \\
\hline 1 & $\mathrm{p}_{1}$ & $45,50 \mathrm{a}$ & - & \\
\hline 2 & $\mathrm{p}_{2}$ & $49,04 \mathrm{a}$ & 108 & 8 \\
\hline 3 & $\mathrm{p}_{3}$ & $49,94 \mathrm{a}$ & 110 & 10 \\
\hline 4 & $\mathrm{p}_{4}$ & $46,92 \mathrm{a}$ & 103 & 3 \\
\hline & & ah cabang & & \\
\hline 1 & $\mathrm{p}_{1}$ & $13,99 \mathrm{a}$ & - & \\
\hline 2 & $\mathrm{p}_{2}$ & $14,07 \mathrm{a}$ & 101 & 1 \\
\hline 3 & $\mathrm{p}_{3}$ & $14,35 \mathrm{a}$ & 103 & 3 \\
\hline 4 & $\mathrm{p}_{4}$ & $14,12 \mathrm{a}$ & 101 & 1 \\
\hline
\end{tabular}

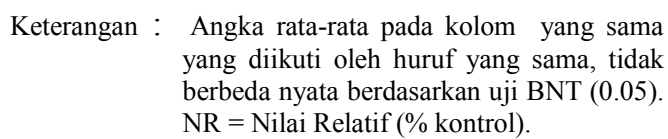

Dari Tabel 1 diatas dapat dilihat bahwa pemberian kompos ampas tebu tidak memberikan 
pengaruh nyata terhadap pertumbuhan tanaman kacang hijau. Namun demikian perubahan yang terjadi menunjukkan adanya terjadi peningkatan, dimana peubah tinggi tanaman mengalami peningkatan yang berkisar antara $3-8 \%$. Sementara itu peubah jumlah cabang primer juga penunjukkan adanya peningkatan yang berkisar antara $1-3 \%$.

Akan tetapi pemberian kompos ampas tebu menunjukkan pengaruh yang nyata terhadap komponen hasil dan hasil tanaman kacang hijau. Pemberian kompos ampas tebu pada peubah jumlah polong per tanaman, jumlah polong berisi per tanaman, bobot 100 biji dan Indeks panen dapat dilihat pada Tabel 2 berikut.

\begin{tabular}{|c|c|c|c|c|}
\hline No & $\begin{array}{c}\text { Perlak } \\
\text { uan }\end{array}$ & $\begin{array}{c}\text { Hasil per } \\
\text { hektar }\end{array}$ & NR & $\begin{array}{c}\text { Perubaha } \\
\mathrm{n}(\%)\end{array}$ \\
\hline 1 & $\mathrm{p}_{1}$ & $1,86 \mathrm{~b}$ & - & - \\
\hline 2 & $\mathrm{p}_{2}$ & $2,07 \mathrm{ab}$ & 111 & 11 \\
\hline 3 & $\mathrm{p}_{3}$ & $1,99 \mathrm{ab}$ & 107 & 7 \\
\hline 4 & $\mathrm{p}_{4}$ & $2,22 \mathrm{a}$ & 119 & 19 \\
\hline \multicolumn{5}{|c|}{ Berat 100 biji } \\
\hline 1 & $\mathrm{p}_{1}$ & $7,30 \mathrm{~b}$ & - & - \\
\hline 2 & $\mathrm{p}_{2}$ & $7,43 \mathrm{ab}$ & 102 & 2 \\
\hline 3 & $\mathrm{p}_{3}$ & $7,46 \mathrm{ab}$ & 102 & 2 \\
\hline 4 & $\mathrm{p}_{4}$ & 7,72 a & 106 & 6 \\
\hline \multicolumn{5}{|c|}{ Nilai indeks panen } \\
\hline 1 & $\mathrm{p}_{1}$ & $0,359 \mathrm{~b}$ & - & - \\
\hline 2 & $\mathrm{p}_{2}$ & $0,377 \mathrm{ab}$ & 105 & 5 \\
\hline 3 & $\mathrm{p}_{3}$ & $0,427 \mathrm{ab}$ & 119 & 19 \\
\hline 4 & $\mathrm{p}_{4}$ & $0,494 \mathrm{a}$ & 138 & 38 \\
\hline & $\begin{array}{r}\text { gan :An } \\
\text { ya } \\
\text { be } \\
(0 .\end{array}$ & $\begin{array}{l}\text { a-rata pada } \mathrm{k} \\
\text { uti oleh huru } \\
\text { yata berdase } \\
\mathrm{R}=\text { Nilai Rel }\end{array}$ & $\begin{array}{l}\text { yang } \\
\text { g sama } \\
\text { uji BN } \\
\% \text { kon }\end{array}$ & \\
\hline
\end{tabular}

Dari Tabel 2 diatas menunjukkan bahwa perlakuan p4 (30 ton/ha kompos ampas tebu) memberikan hasil tertinggi pada hasil per hektar, bobot 100 biji dan nilai indeks panen, yang berbeda nyata dengan perlakuan p0 (tanpa kompos), namun tidak berbeda nyata dengan perlakuan $\mathrm{p} 2$ dan $\mathrm{p} 3$ (10 ton $\mathrm{ha}^{-1}$ dan 20 ton $\mathrm{ha}^{-1}$. Perubahan yang terjadi juga menunjukkan bahwa perlakuan $\mathrm{p} 4$ memberikan peningkatan lebih tinggi dibandingkan perlakuan lainnya.

Suhu udara yang optimal untuk pertumbuhan vegetatif dan generatif pada

tanaman kacang hijau berkisar antara 25-27 ${ }^{\circ} \mathrm{C}$ (Balai Pengkajian Teknologi Pertanian, 2015). Hasil penelitian menunjukkan bahwa suhu selama percobaan sudah sesuai dengan syarat tumbuh kacang hijau yaitu ratarata $27-28{ }^{\circ} \mathrm{C}$. Suhu tersebut juga diduga sesuai untuk perkembangan fase generatif kacang hijau, sehingga menyebabkan pemasakan polong menjadi jauh lebih cepat dimana polong sudah siap panen pada umur 51 HST sedangkan pada deskripsi polong siap panen pada umur 60-70 HST.

Pembentukan polong juga terjadi lebih cepat yang diduga diakibatkan karena pembungaan yang lebih awal, yang selanjutnya mengakibatkan pembentukan biji juga lebih cepat. Selain faktor genetik, ketersediaan hara $\mathrm{P}$ juga memicu peningkatan persentase bunga menjadi buah/biji, membantu asimilasi sekaligus mempercepat pemasakan buah dan mempengaruhi berat biji (Sutarwi et al., 2013). Hal tersebut dapat dilihat dari bobot 100 biji dengan rata-rata 100 biji mencapai $7,72 \mathrm{~g}$ yang telah melebihi berat dari deskripsi yaitu 6.07.0 g per 100 biji.

Upaya meningkatkan hasil panen kacang hijau yang dilakukan dapat dikatakan berhasil karena hasil yang 
diperoleh yaitu rata-rata 2,22 ton $\mathrm{ha}^{-1}$ telah melebihi daya hasil kacang hijau Varietas Kutilang pada data deskripsi (1,96-ton $\left.\mathrm{ha}^{-1}\right)$. Disamping itu juga dari nilai indeks panen dapat dilihat bahwa perlakuan p4 memberikan nilai indeks panen sebesar 0, 494 yang berbeda nyata dengan indeks panen pada perlakuan p0 yaitu sebesar 0,359 .

\section{Kesimpulan dan Saran}

Kesimpulan

1. Pupuk kompos ampas tebu dapat meningkatkan hasil tanaman kacang hijau.

2. Pupuk kompos ampas tebu berpengaruh terhadap bobot 100 biji, hasil perhektar dan nilai indeks panen hasil kacang hijau.

3. Pupuk kompos ampas tebu 10, 20 dan 30ton ha $^{-1}$ tidak berbeda nyata satu sama lain, tetapi berbeda nyata dengan tanpa pemberian kompos ampas tebu.Saran

Berdasarkan hasil penelitian dapat disarankan untuk menggunakan pupuk kompos ampas tebu sebanyak 10ton $\mathrm{ha}^{-1}$ untuk menggantikan setengah dosis anjuran pupuk anorganik.

\section{Daftar Pustaka}

Balai Penelitian Tanaman Kacangkacangan dan Umbi-umbian. 2005. Teknik Budidaya Kacang Hijau.

www.balitkabi.litbang.pertanian. go.id. (Diakses 25 Oktober 2017).

Balai Pengkajian Teknologi Pertanian. 2015. Bertanam Kacang Hijau. www.nad.litbang.pertanian.go.id/ ind/index.php/infoteknologi/699-bertanam-kacanghijau. (Diakses 25 Oktober 2017).
Bimasri, J. 2014. Peningkatan produksi tanaman kacang hijau (Vigna radiata L.) di tanah gambut melalui pemberian pupuk $\mathrm{N}$ dan P. Prosiding Seminar Nasional Lahan Suboptimal 613-620.

Guntoro, D., Purwonodan Sarwono. 2003. Pengaruh pemberian kompos bagase terhadap pertumbuhan serapan hara dan pertumbuhan tanaman tebu (Saccharum officinarum L.). Bul. Agron 31(2):112-119.

Lasmaria, Y., L. Fitriani dan Seprianingsih. 2016. Pengaruh pupuk organik terhadap pertumbuhan kacang hijau (Phaseolus ratiatus L.). Hal:1-7.

Marum, J., D. Zulfita dan Mulyadi. 2012. Pengaruh kompos ampas tebu terhadap pertumbuhan dan hasil tanaman lobak pada tanah podsolid merah kuning. Program Studi Agronomi Universitas Tanjungpura. Hal:1-16.

Musnamar, E.I. 2003. Pembuatan dan Aplikasi Pupuk Organik Padat. Penebar Swadaya. Jakarta.

Prasetyo, B.H. dan D.A. Suriadikarta. 2006. Karakteristik, potensi, dan teknologi pengolahan tanah ultisol untuk pengembangan pertanian lahan kering di Indonesia. Jurnal Litbang Pertanian 25(2):39-47.

Standar Nasional Indonesia. 2004. Standar Kualitas Kompos. www.ciptakarya.pu.go.id. (Diakses 23 November 2017)

Soeprapto. 1993. Bertanam Kacang Hijau. Penebar Swadaya. Jakarta.

Yuliani, F. Dan F. Nugraheni. 2010. Pembuatan pupuk organik (Kompos) dari arang ampas tebu dan limbah ternak. Hal:1-11 